\title{
Laju Pertumbuhan Eksplan Rumput Laut (Gracilaria verrucosa (Hudson) Papenfuss) secara in vitro
}

\author{
Muhammad Evan Nurrahmawan dan Nurul Jadid \\ Departemen Biologi, Fakultas Matematika dan Ilmu Pengetahuan Alam, Institut Teknologi Sepuluh \\ Nopember (ITS) \\ e-mail: nuruljadid@bio.its.ac.id
}

\begin{abstract}
Abstrak-Pada tahun 2016, kebutuhan Agar dunia mencapai 550.000 ton dan terus meningkat tiap tahunnya. Peningkatan kebutuhan tersebut harus diiringi dengan peningkatan produksi rumput laut. Gracilaria verrucosa merupakan rumput laut penghasil Agar dan banyak dibudidayakan di Indonesia. Akan tetapi, produksi rumput laut $G$. verrucosa masih rendah disebabkan oleh laju pertumbuhan yang lambat. Selain itu, penyediaan bibit unggul juga masih sulit dilakukan. Teknik kultur in vitro melalui penambahan ZPT auksin dan sitokinin diketahui dapat meningkatkan laju pertumbuhan eksplan. Oleh karena itu, penelitian bertujuan untuk mengetahui pengaruh kombinasi ZPT IAA dan BAP terhadap laju pertumbuhan rumput laut $G$. verrucosa secara in vitro. Penelitian dilakukan dengan menumbuhkan eksplan interkalar $G$. verrucosa ke dalam medium PES dengan penambahan kombinasi IAA dan BAP (0; $0,1 ; 0,3 ; 0,5 \mathrm{mg} / \mathrm{l})$ selama 30 hari. Hasil penelitian menunjukkan kombinasi IAA dan BAP berpengaruh terhadap laju pertumbuhan eksplan rumput laut $G$. verrucosa. Perlakuan IAA $0 \mathrm{mg} / \mathrm{l}$ dan BAP $0,5 \mathrm{mg} / \mathrm{l}$ menunjukkan pengaruh tertinggi terhadap laju pertumbuhan yakni sebesar $0,42 \%$ per hari.
\end{abstract}

Kata Kunci-BAP, Gracilaria verrucosa, IAA, In vitro, Laju Pertumbuhan.

\section{PENDAHULUAN}

$\mathrm{R}$ UMPUT laut Gracilaria verrucosa merupakan salah satu jenis alga merah (Rhodophyta) penghasil agar (agarofit) dengan kandungan agar mencapai 47,34\% [1]. Agar banyak digunakan sebagai bahan pengental dan pengemulsi dalam industri makanan, obat-obatan, kosmetik, kertas, tekstil, minyak bumi, dan industri bioteknologi [2][3].

Berdasarkan data KKP [4], kebutuhan agar dunia pada tahun 2016 mencapai 550.000 ton dan terus meningkat setiap tahunnya. Seiring dengan meningkatnya kebutuhan Agar, peningkatan produksi rumput laut $G$. verrucosa juga perlu ditingkatkan. Akan tetapi, produksi rumput laut $G$. verrucosa melalui budidaya tambak masih banyak mengalami kendala yang berakibat pada menurunnya produksi. Hal ini dibuktikan pada rendahnya produksi rumput laut $G$. verrucosa di Kecamatan Jabon, Kabupaten Sidoarjo yang hanya mencapai 1.344 ton rumput laut kering pada tahun 2016 [5].

Salah satu kendala yang dihadapi adalah laju pertumbuhan rumput laut yang lambat sehingga berakibat pada rendahnya produksi rumput laut [6]. Selain itu, penyediaan bibit unggul juga masih terbatas pada teknik konvensional melalui perbanyakan vegetatif. Padahal penggunaan teknik tersebut secara berulang diketahui dapat menurunkan laju pertumbuhan [7][8].

Perkembangan bioteknologi seperti kultur in vitro telah dikembangkan untuk meningkatkan produksi rumput laut $G$. verrucosa. Proses kultur in vitro dapat dipengaruhi oleh faktor endogen dan eksogen. Faktor endogen meliputi karakteristik eksplan seperti umur, sumber, tahap perkembangan dan fisiologi, sedangkan faktor eksogen meliputi salinitas, iradiasi, fotoperiodisasi, temperatur, $\mathrm{pH}$ dan komposisi media [9]. Laju pertumbuhan tinggi dapat dicapai melalui pengamatan dan pengendalian faktor abiotik yang diketahui berpengaruh terhadap pertumbuhan spesies [10]. Sebagai hasil, penyediaan bibit unggul dalam jumlah dapat diproduksi dalam waktu yang singkat sehingga mendukung produksi rumput laut secara berkelanjutan yang bertujuan untuk memenuhi kebutuhan Agar [8].

Yong et al. [11] melaporkan bahwa penggunaan zat pengatur tumbuh (ZPT) Indole-3-acetic acid (IAA) dan 6Benzylaminopurine (BAP) pada kultur rumput laut Kappaphycus alvarezii secara in vitro dapat meningkatkan laju pertumbuhan eksplan secara optimum yakni sebesar $4 \%$ per hari sedangkan pada kultur yang tidak ditambahkan ZPT memiliki laju pertumbuhan lebih rendah yakni sebesar $1,8 \%$ per hari. Hal tersebut menunjukkan bahwa penggunaan ZPT sebagai faktor eksogen berperan dalam meningkatkan laju pertumbuhan.

Oleh karena itu, penelitian ini bertujuan untuk mengetahui pengaruh kombinasi ZPT IAA dan BAP terhadap laju pertumbuhan eksplan rumput laut $G$. verrucosa secara in vitro.

\section{METODE PENELITIAN}

\section{A. Waktu dan Tempat Penelitian}

Penelitian ini dilaksanakan pada bulan Januari 2017 sampai Mei 2017 di Laboratorium Biosains dan Teknologi Tumbuhan, Departemen Biologi, Fakultas Matematika dan Ilmu Pengetahuan Alam, Institut Teknologi Sepuluh Nopember.

\section{B. Pengambilan Sampel}

Pengambilan sampel rumput laut menggunakan metode semi-basah berdasarkan penelitian Sulistiani dan Yani [12] dengan modifikasi. Rumput laut diambil dari tambak budidaya di Desa Kupang, Kecamatan Jabon, Kabupaten Sidoarjo, Jawa 
Timur (7³1'21.3"S 11249'34.0"E). Sampel dibersihkan terlebih dahulu dari kotoran dan organisme yang menempel (epifit). Setelah bersih, sampel dimasukkan ke dalam cool box dalam keadaan basah dan disusun tidak rapat kemudian dilapisi dengan koran pada bagian atas. Setelah itu, cool box ditutup rapat dan siap untuk dibawa ke laboratorium..

\section{Sterilisasi Eksplan}

Sterilisasi eksplan bertujuan untuk mendapatkan eksplan steril yang bersih dari kontaminan. Perlakuan sterilisasi eksplan diakukan berdasarkan penelitian Reddy et al. [13] dengan modifikasi. Sampel hasil aklimatisasi dibawa ke dalam LAF dan dipotong bagian thallus apikal dengan panjang \pm 5 $\mathrm{cm}$ dan dibilas dengan air laut steril sebanyak 2 kali. Setelah itu, eksplan direndam ke dalam $0,1 \%(w / v)$ larutan deterjen (Rinso) selama 10 menit. Kemudian eksplan direndam ke dalam $1 \%(\mathrm{v} / \mathrm{v})$ larutan povidone iodine (Betadine) selama 1 menit. Pada tiap perlakuan, eksplan dibilas dengan air laut steril sebanyak 2 kali. Selanjutnya, eksplan direndam ke dalam $3 \%$ (v/v) larutan medium PES Antibiotik selama 48 jam. Kultur disimpan diatas rotary shaker dengan temperatur ruang $22-25^{\circ} \mathrm{C}$, intensitas cahaya 1500 lux, dan penyinaran terang:gelap (12:12 jam). Setelah itu, eksplan dibilas dengan air laut steril sebanyak 2 kali dan dikeringkan dengan tisu steril. Eksplan steril telah siap untuk digunakan untuk tahap selanjutnya.

\section{Inokulasi Eksplan}

Inokulasi eksplan dilakukan berdasarkan penelitian Sulistiani dan Yani [12] dengan modifikasi. Eksplan steril dipotong dengan panjang $\pm 0,5 \mathrm{~cm}$ (berat $\pm 0,5 \mathrm{mg}$ ) di dalam LAF. Kemudian potongan eksplan dimasukkan ke dalam gelas kultur berisi 2\% (v/v) medium PES padat. Setiap botol berisi 5 eksplan yang disusun melingkar. Setelah itu, gelas kultur ditutup kembali dengan plastik HDPE dan disimpan dalam rak kultur selama 4 minggu dengan temperatur ruangan $22-25^{\circ} \mathrm{C}$, intensitas cahaya 1500 lux, dan penyinaran terang:gelap (12:12 jam).

\section{E. Pengamatan}

Pengamatan laju pertumbuhan eksplan dilakukan dengan menggunakan rumus sebagai berikut:

Keterangan

$$
\mathrm{GR}=[\mathrm{LN}(\mathrm{Wt} / \mathrm{W} 0) / \mathrm{t}] \times 100 \%
$$

GR : Laju pertumbuhan eksplan (\%)

Wt : Berat akhir eksplan (mg)

Wo : Berat awal eksplan (mg)

t : Lamanya kultur (hari)

Pengamatan induksi tunas dilakukan dengan menghitung persentase eksplan bertunas menggunakan rumus sebagai berikut:

Keterangan

$$
\mathrm{C}=\frac{E t}{E 0} \times 100
$$

C : Laju persentase eksplan bertunas (\%)

Et : Total jumlah eksplan akhir yang bertunas
Eo : Total jumlah eksplan awal tanam

Sedangkan pengamatan multiplikasi tunas dilakukan dengan menghitung jumlah tunas per eksplan yang muncul setelah 30 hari inokulasi.

\section{F. Rancangan Penelitian dan Analisis Data}

Penelitian disusun menggunakan Rancangan Acak Lengkap (RAL) faktorial dengan dua faktor. Faktor pertama adalah IAA dengan 4 level konsentrasi $(0 ; 0,1 ; 0,3 ; 0,5 \mathrm{mg} / \mathrm{l})$ sedangkan faktor kedua adalah BAP dengan 4 level konsentrasi $(0 ; 0,1 ; 0,3 ; 0,5 \mathrm{mg} / \mathrm{l})$. Penelitian terdiri dari 16 perlakuan dengan 5 kali ulangan. Parameter uji yang dilakukan adalah laju pertumbuhan eksplan.

Data pengamatan laju pertumbuhan eksplan dianalisis menggunakan uji ANOVA Two Way menggunakan program Minitab 16 untuk mengetahui pengaruh kombinasi IAA dan BAP terhadap laju pertumbuhan eksplan rumput laut $G$. verrucosa. Analisis dilanjutkan dengan uji Tukey dengan taraf signifikan $5 \%$ untuk mengetahui perbandingan antar perlakuan IAA dan BAP.

\section{HASIL DAN PEMBAHASAN}

\section{A. Laju Pertumbuhan Eksplan}

Pengamatan laju pertumbuhan bertujuan untuk mengetahui adanya pertumbuhan pada eksplan melalui pengukuran selisih berat awal dan berat akhir selama dikultur dalam medium PES dengan penambahan kombinasi IAA dan BAP. Pada penelitian ini, kombinasi IAA dan BAP berpengaruh terhadap laju pertumbuhan eksplan.

Pada pengamatan laju pertumbuhan, perlakuan BAP tanpa penambahan IAA menunjukkan respon peningkatan laju pertumbuhan seiring dengan tingginya rasio BAP. Akan tetapi, pada perlakuan IAA tanpa penambahan BAP dan kombinasi keduanya menunjukkan variasi respon peningkatan dan penurunan laju pertumbuhan. Kombinasi IAA dan BAP dengan rasio yang sama menunjukkan penurunan laju pertumbuhan seiring dengan meningkatnya rasio perlakuan kedua ZPT tersebut. Berdasarkan hasil uji ANOVA, interaksi IAA dan BAP berpengaruh signifikan terhadap laju pertumbuhan $(\mathrm{P}<0,05)$.

Berdasarkan hasil pengamatan laju pertumbuhan eksplan (Tabel 4.1), perlakuan IAA $0 \mathrm{mg} / \mathrm{l}$ dan BAP $0,5 \mathrm{mg} / \mathrm{l}$ menunjukkan respon tertinggi terhadap laju pertumbuhan eksplan yakni sebesar $0,42 \%$ per hari dan tidak berbeda signifikan dengan perlakuan lain yang diikuti oleh huruf yang sama. Sedangkan perlakuan IAA $0,5 \mathrm{mg} / \mathrm{l}$ dan BAP $0,5 \mathrm{mg} / \mathrm{l}$ menunjukkan respon terendah yakni sebesar $0,1 \%$ per hari dan tidak berbeda signifikan dengan perlakuan lain yang diikuti dengan huruf yang sama. Pada perlakuan IAA $0 \mathrm{mg} / \mathrm{l}$ dan BAP $0 \mathrm{mg} / \mathrm{l}$ juga menunjukkan respon laju pertumbuhan yakni sebesar $0,17 \%$. Hal ini diduga karena adanya hormon endogen yang berperan dalam meningkatkan pertumbuhan. Beberapa tipe hormon tanaman secara alami memang terdapat dalam jaringan rumput laut baik auksin dan sitokinin (endogenus auksin/sitokinin), seperti IAA, ABA (Abscisic acid), PAA (Phenyl acetic acid), iP (isopentenyladenin), and CZ (ciszeatin) [14][15]. 
Tabel 1.

Pengaruh kombinasi IAA dan BAP terhadap laju pertumbuhan eksplan rumput laut G. verrucosa

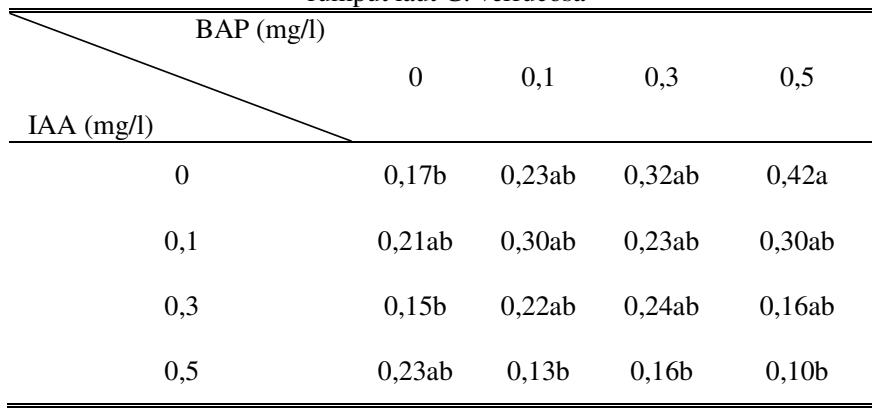

Keterangan: Angka yang diikuti huruf yang sama tidak berbeda signifikan menurut uji Tukey dengan taraf signifikan 5\%.

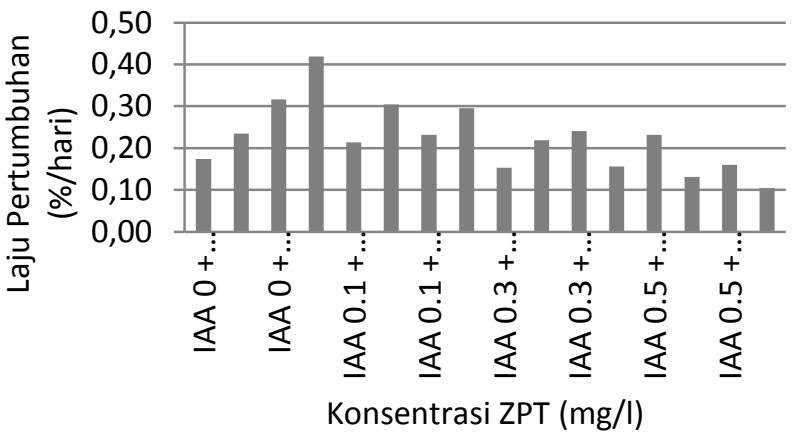

Gambar 1. Grafik pengaruh IAA dan BAP terhadap laju pertumbuhan eksplan rumput laut $G$. verruocsa.

Penelitian Yokoya et al. [16] menunjukkan pengaruh auksin dan sitokinin pada laju pertumbuhan rumput laut Gracilaria tenuifrons berkaitan dengan fungsi auksin dan sitokinin dalam proses pembelahan sel, elongasi dan diferensiasi. Auksin berperan dalam mengatur pertumbuhan dan pemanjangan sel, sedangkan sitokinin berperan dalam pembelahan sel dan morfogenesis [17]. Penelitian lainnya melaporkan bahwa kombinasi IAA $1 \mathrm{mg} / \mathrm{l}$ dan BAP 2,5 mg/l meningkatkan laju pertumbuhan eksplan rumput laut Kappaphycus alvarezii secara optimum yakni sebesar $4 \%$ per hari [18].

Pertumbuhan pada tingkat seluler didefinisikan sebagai kenaikan jumah material hidup yang mengakibatkan peningkatan ukuran sel dan selanjutnya akan mempengaruhi pembelahan sel [19]. Hubungan antara pertumbuhan (peningkatan biomasa tiap sel) dan produksi sel baru (siklus sel) sangatlah penting dalam perkembangan organisme multiselular [20][21] dan [22]. Pertumbuhan dan siklus sel dikendalikan oleh perubahan ekspresi gen cyclin-dependent kinase (CDK) dan cyclin akibat pengaruh auksin dan sitokinin. Auksin berperan dalam proses perubahan ekspresi gen meliputi peningkatan aktivitas dan jumlah RNA polimerase, level RNA ribosom, level mRNA protein ribosom dan polyribosom [23]. Sedangkan sitokinin berperan dalam proses sintesis protein spesifik selama tahap siklus sel [24].

Dalam siklus sel, auksin berperan dalam menginduksi ekspresi CDK [25][26] dan [27], menghambat inhibitor CDK (KRP1/KRP2) [28][29], meningkatkan stabilitas protein E2FA/B [30], menstimulus degradasi SKP2A, menginduksi ekspresi telomerase pada fase $\mathrm{S}$ melalui peningkatan aktivitas telomerase selama replikasi [31]. Sedangkan sitokinin berperan dalam menginduksi ekspresi gen cdc2 pada fase transisi G2-M [25], dan menginduksi ekspresi CycD3 pada fase G1-S [32].

\section{KESIMPULAN}

Dalam penelitian ini, pemberian kombinasi IAA dan BAP berpengaruh terhadap induksi dan multiplikasi tunas eksplan rumput laut $G$. verrucosa secara in vitro. Perlakuan dengan hasil tertinggi terdapat pada penambahan IAA $0 \mathrm{mg} / \mathrm{l}$ dan BAP $0,5 \mathrm{mg} / \mathrm{l}$ dengan laju pertumbuhan sebesar $0,42 \%$ per hari.

Saran untuk penelitian selanjutnya yakni dilakukan penelitian tentang optimasi kondisi faktor eksogen (salinitas, komposisi medium, iradiasi, fotoperiodisasi, $\mathrm{pH}$, dan temperatur) pada kultur in vitro rumput laut $G$. verrucosa.

\section{UCAPAN TERIMA KASIH}

Penulis mengucapkan terimakasih kepada Kelompok Tani Tunas Hijau Kupang Sidoarjo dan Laboratorium Kultur Jaringan Biotrop Bogor yang telah memberikan dana bantuan penelitian, Laboratorium Biosains dan Teknologi Tumbuhan Departemen Biologi, FMIPA ITS yang telah menyediakan fasilitas laboratorium penelitian dan Dr. Nurul Jadid, M.Sc yang telah membimbing penulis dalam penelitian ini.

\section{DAFTAR PUSTAKA}

[1] A. Kadi and W. S. Atmadja, "Rumput Laut (Algae) Jenis, Reproduksi, Produksi, Budidaya dan Pasca Panen," Jakarta, 1988.

[2] FAO, "World Aquaculture," Rome, 2014.

[3] M. Glicksman, Food Hydrocolloid. Volume II. New York: CRC Press, 1983.

[4] KKP, “Mina Bahari Edisi 4,” Jakarta, 2016.

[5] Badan Pusat Statistik Sidoarjo, "Statistik Kecamatan Jabon 2016," Sidoarjo, 2016.

[6] E. S. A. Parenrengi and R. Syah, "Penyediaan Benih dalam Menunjang Kebun Bibit dan Budidaya Rumput Laut Kappaphycus alvarezii," Jakarta, 2007.

[7] P. R. P. Masak, A. Panrenrengi, and R. M. Tjaronge, "Protokol Seleksi Varietas Bibit Unggul Rumput Laut," Jakarta, 2011

[8] A. Q. Hurtado and D. P. Cheney, "Propagule Production of Eucheuma denticulatum (Burman) Collins et Harvey by Tissue Culture," Bot Mar, pp. 338-341, 2003.

[9] N. S. Yokoya and Y. Yoneshique-Valentin, "Micropropagation as a Tool for Sustainable Utilization and Conservation of Populations of Rhodophyta," Rev. Bras. Farm., vol. 21, pp. 334-339, 2011.

[10]C. H. Yu, P. E. Lim, and S. M. Phang, "Effects of Irradiance and Salinity on The Growth of Carpospore-derived Tetrasporophytes of Gracilaria edulis and Gracilaria tenuistipitata var liui (Rhodophyta)," J. Appl. Phycol, vol. 25, pp. 787-794, 2013.

[11]W. T. L. Yong et al., "Optimization of Culture Conditions for The Direct Regeneration of Kappaphycus alvarezii (Rhodophyta, Solireiaceae)," $J$ Appl Phycol, 2013.

[12]E. Sulistiani, D. T. Soelistyowati, Alimuddin, and S. A. Yani, "Callus Induction and Filaments Regeneration from Callus of Cottonii Seaweed (Kappaphycus alvarezii) Collected from Natuna Islands, Riau Islands Province," Biotropia (Bogor)., vol. 19, no. 2, pp. 103-144, 2012.

[13]C. R. K. Reddy, K. G. Rajakrishna, A. K. Siddhanata, A. Tewari, and K. Eswaran, "In vitro Somatic Embryogenesis and Regeneration of Somatic Embryos from Pigmented Callus of Kappaphycus alvarezii (Doty) Doty (Rhodophyta, Gigartinales)," J Phycol, vol. 39, pp. 610-616, 2003.

[14]P. M. Bradley and D. P. Cheney, "Some Effects of Plant Regulators on Tissue Cultures of the Marine Red Alga Agardhiella subulata (Gigartinales, Rhodophyta)," Hydrobiologia, vol. 204/205, pp. 353-360, 1991. 
[15]N. S. Yokoya, W. A. Stirk, van J. Staden, O. Novak, and A. V. Tureckova, "Pencik and M. Strnad. Endogenous Cytokinins, Auxin, and Abscisid Acid in Red Algae from Brazil," J. Phycol, vol. 46, pp. 1198$1205,2010$.

[16]Z. Y. Maryani, "Penggandaan Tunas Krisan melalui Kultur Jaringan," Ilmu Pertan., vol. 12, no. 1, pp. 51-55, 2010.

[17]P. F. Wareing and I. D. J. Phillips, Growth and Differentiation in Plant. Oxford: Pergamon Press, 1981.

[18] A. Sahraroo, M. Babalar, M. H. Mirjalili, M. R. F. Moghaddam, and S. N. Ebrahimi, "In-vitro Callus Induction and Rosmarinic Acid Quantification in Callus Culture of Satureja khuzistanica Jamzad (Lamiaceae)," $J$. Pharm. Res., vol. 13, no. 4, pp. 1447-1456, 2014.

[19]H. Stocker and E. Hafen, "Genetic Control of Cell Size," Curr Opin Genet Dev, vol. 10, pp. 529-535, 2000.

[20]D. D. Hall, D. D. Markwardt, F. Parviz, and W. Heideman, "Regulation of The Cln3-Cdc28 Kinase by cAMP in Saccharomyces cerevisiae," EMBO J, vol. 17, pp. 4370-4378, 1998.

[21]P. Jorgensen and M. Tyers, "How Cells Coordinate Growth and Division," Curr Biol, vol. 14, pp. R1014-R1027, 2004.

[22] T. Ulmasov, Z. B. Liu, G. Hagen, and T. J. Guilfoyle, "Composite Structure of Auxin Response Elements," Plant Cell, vol. 7, pp. 16111623, 1997.

[23] M. L. Evans, Function of hormones at the cellular of organisation. Berlin: Springer Verlag, 1984.

[24]A. S. Hemerly et al., "cdc2a Expression in Arabidopsis is Linked with Competence for Cell Division.," Plant Cell, vol. 5, pp. 1711-1723, 1993.

[25]P. C. Ferreira, A. S. Hemerly, J. D. Engler, M. van Montagu, G. Engler, and D. Inze, "Developmental Expression of the Arabidopsis Cyclin Gene Cyc1At," Plant Cell, vol. 6, pp. 1763-1774, 1994.

[26]P. Doerner and J. Celenza, How are Plant Growth Regulators Involved in Cell Cycle Control? in Plant Hormone Research (ed. K. Palme, J. Schell). Springer, 2000.

[27]C. Richard, C. Granier, D. Inze, and L. De Veylder, "Analysis of Cell Division Parameters and Cell Cycle Gene Expression during The Cultivation of Arabidopsis thaliana Cell Suspensions," J Exp Bot, vol. 51, pp. 1625-1633, 2001.

[28] K. Himanen, E. Boucheron, S. Vanneste, J. de Almeida, D. I. Engler, and T. Beeckman, "Auxin-mediated Cell Cycle Activation During Early Lateral Root Initiation,” Plant Cell, vol. 14, pp. 2339-2351, 2002.

[29]Z. Magyar, L. De Veylder, A. Atanassova, L. Bako, D. Inze, and L. Bogre, "The Role of the Arabidopsis E2FB Transcription Factor in Regulating Auxin-dependent Cell Division," Plant Cell, vol. 17, pp. 2527-2541, 2005.

[30] K. Tamura, H. Liu, and H. Takahashi, "Auxin Induction of Cell Cycle Regulated Activity of Tobacco Telomerase," J Biol Chem, vol. 274, pp. 20997-21002, 1999.

[31]R. Soni, J. P. Carmichael, Z. H. Shah, and J. A. H. Murray, “A Family of Cyclin D Homologs from Plants Differentially Controlled by Growth Regulators and Containing The Conserved Retinoblastoma Protein Interaction Motif," Plant Cell, vol. 7, pp. 85-103, 1995.

[32]N. S. Yokoya and W. Handro, "Effects of Plant Growth Regulators and Culture Medium on Morphogenesis of Solieria filiformis (Rhodophyta) Cultured in vitro," J Appl Phycol, vol. 14, pp. 97-102, 2002. 